\title{
Relative contribution of monsoon precipitation and pumping to changes in groundwater storage in India
}

\begin{abstract}
Akarsh Asoka1, Tom Gleeson ${ }^{2}$, Yoshihide Wada ${ }^{3,4,5,6}$ and Vimal Mishra ${ }^{1 \star}$
The depletion of groundwater resources threatens food and water security in India. However, the relative influence of groundwater pumping and climate variability on groundwater availability and storage remains unclear. Here we show from analyses of satellite and local well data spanning the past decade that long-term changes in monsoon precipitation are driving groundwater storage variability in most parts of India either directly by changing recharge or indirectly by changing abstraction. We find that groundwater storage has declined in northern India at the rate of $2 \mathrm{~cm} \mathrm{yr}^{-1}$ and increased by 1 to $2 \mathrm{~cm} \mathrm{yr}^{-1}$ in southern India between 2002 and 2013. We find that a large fraction of the total variability in groundwater storage in north-central and southern India can be explained by changes in precipitation. Groundwater storage variability in northwestern India can be explained predominantly by variability in abstraction for irrigation, which is in turn influenced by changes in precipitation. Declining precipitation in northern India is linked to Indian Ocean warming, suggesting a previously unrecognized teleconnection between ocean temperatures and groundwater storage.
\end{abstract}

S ignificant depletion of groundwater storage in a number of regions around the world, including northwest India ${ }^{1,2}$, has been shown with Gravity Recovery Climate Experiment (GRACE) observational data as well as global hydrologic and water use models ${ }^{3,4}$, and attributed to groundwater pumping (abstraction) for irrigation ${ }^{1,2,5,6}$. In India, irrigated agriculture produces over $70 \%$ of food grain, and groundwater plays a major role ${ }^{7}$, with annual groundwater abstraction increasing from $10-20 \mathrm{~km}^{3} \mathrm{yr}^{-1}$ to $240-$ $260 \mathrm{~km}^{3} \mathrm{yr}^{-1}$ between 1950 and $2009^{8}$. India is a global leader in groundwater-fed irrigation due to intensive agriculture driven by multiple crops in a year ${ }^{9}$, especially after the green revolution ${ }^{1,2}$, with the largest non-renewable groundwater abstraction $\left(68 \mathrm{~km}^{3} \mathrm{yr}^{-1}\right)$ in the world ${ }^{7}$. Persistent droughts can reduce groundwater recharge and enhance groundwater pumping for irrigation, leading to lowered groundwater levels. For instance, due to a continuous deficit in precipitation, $80 \mathrm{~km}^{3}$ of groundwater has been depleted in southern California since $1960^{5}$. Over the Gangetic Plain and other parts of north India, the monsoon season (June to September) precipitation has declined since $1950^{10-12}$, which has led to increased frequency and intensity of droughts ${ }^{13}$, possibly contributing to enhanced abstraction and/or reduced recharge of groundwater. Using multiple data sources (GRACE, well observations, model $\left(\right.$ PCR-GLOBWB ${ }^{14}$ ), precipitation, and sea surface temperature (SST)) and methods (regression and dominance analysis), we explore two related hypothesis: that precipitation deficit may have an impact on declining groundwater levels in northwestern India, which have previously been largely attributed to abstraction for irrigation ${ }^{2}$, and that groundwater storage variability may be partially associated with large-scale climate effects ${ }^{15}$, since weakening of the monsoon season precipitation is linked to largescale climate variability ${ }^{10,12}$.

\section{Changes in groundwater storage}

We estimated groundwater storage anomalies from GRACE for 2002-2013 to evaluate the spatial patterns of changes in groundwater in north and south India (Fig. 1). Consistent with previous analysis, and further supported for the first time by comparison to a large data set of water-level observations, GRACE groundwater anomalies show significant declines $\left(2 \mathrm{~cm} \mathrm{yr}^{-1}, p\right.$-value $\left.<0.05\right)$ in the majority of north India in January, May, August, and November for which observations from Central Groundwater Board (CGWB) are available (Fig. 1a-d and Supplementary Fig. 3). Moreover, changes in groundwater anomalies from GRACE show increases $\left(\sim 1-2 \mathrm{~cm} \mathrm{yr}^{-1}\right.$, change in linear units) in south India (Fig. 1a-d and Supplementary Fig. 3). We find that changes in groundwater level from the observation wells and GRACE are consistent for 2002-2013 (Fig. 2e-h). However, GRACE-based estimates of trends are lower than those of observation wells, as GRACE examines larger spatial domains $(\sim 100 \mathrm{~km}$ grid), whereas well observations are for point scale and represent very local depletion, which is not visible at GRACE resolution. However, standardized anomalies of groundwater level and GRACE-based groundwater storage change showed a close correspondence for north and south India, with correlation coefficients of 0.46 and -0.77 respectively (Fig. 1i,j). GRACE groundwater anomalies show a large pattern of declining groundwater in north India, but increasing groundwater level in south India. However, it is unclear if these patterns of changes in groundwater anomalies in north and south India are driven by groundwater abstraction for irrigation or long-term changes in precipitation.

Previous studies ${ }^{1,2,11}$ reported declines in groundwater storage in north India based on GRACE data, which are available for 2002 onwards; however, quantification of groundwater storage

${ }^{1}$ Civil Engineering and Earth Sciences, Indian Institute of Technology (IIT), Gandhinagar India. ${ }^{2}$ Department of Civil Engineering and School of Earth and Ocean Sciences, University of Victoria, Canada. ${ }^{3}$ NASA Goddard Institute for Space Studies, New York ${ }_{\lambda}$ USA. ${ }^{4}$ Center for Climate Systems Research, Columbia University, New York, USA. ${ }^{5}$ Department of Physical Geography, Utrecht University, Utrecht, The Netherlands. ${ }^{6}$ International Institute for Applied Systems Analysis, Laxenburg, Austria. *e-mail: vmishra@iitgn.ac.in 

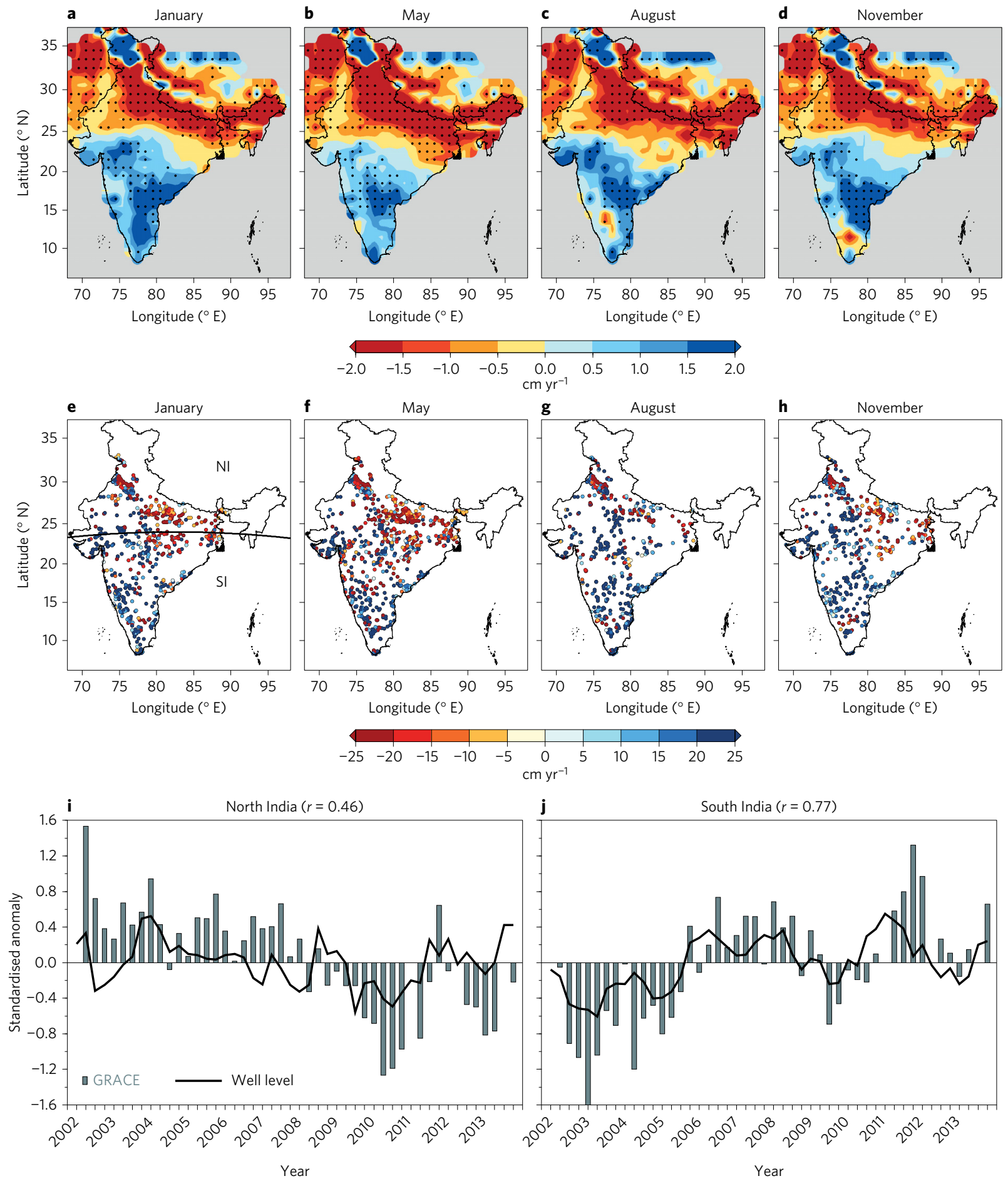

Figure 1 | Changes in groundwater storage from observation well and GRACE data during 2002-2013. a-h, Monthly trends in groundwater anomaly are from GRACE (in $\mathrm{cm} \mathrm{yr}^{-1}$ ) (a-d) and in situ well observations from the CGWB (e-h) for 2002-2013. Stippling in a-d indicates statistically significant changes at the $5 \%$ level. e-h, Wells that experienced significant declines and increases in groundwater levels $\left(\mathrm{cm} \mathrm{yr}^{-1}\right.$ ) during 2002-2013. Trends were estimated using the non-parametric Mann-Kendall test and Sen's slope method. Monthly anomalies for January, May, August, and November were estimated from GRACE and in situ observations after removing the monthly mean. In situ groundwater well observations from the CGWB are available only for four months (January, May, August, and November). i,j, Area-averaged standardized departure (after removing mean and dividing by the standard deviation) from GRACE and in situ well observations for north (above $23^{\circ} \mathrm{N}$ ) and south (below $23^{\circ} \mathrm{N}$ ) India, respectively. Correlation coefficients between standardized anomalies of GRACE and groundwater wells for north and south India are 0.46 and 0.77 , respectively.

variability in India beyond the GRACE period is limited. We estimated changes (using linear trend) in the groundwater table depth (m) using well observations from the CGWB for 1996-2013 and applied the non-parametric Mann-Kendall trend test and Sen's slope method. Moreover, we used the field significance test ${ }^{16}$ to evaluate trends at a regional scale considering the influence of spatial and temporal correlations. Results show a significant decline $(\sim 15-$ $25 \mathrm{~cm} \mathrm{yr}^{-1}, p$-value $\left.<0.05\right)$ in groundwater table depth during 

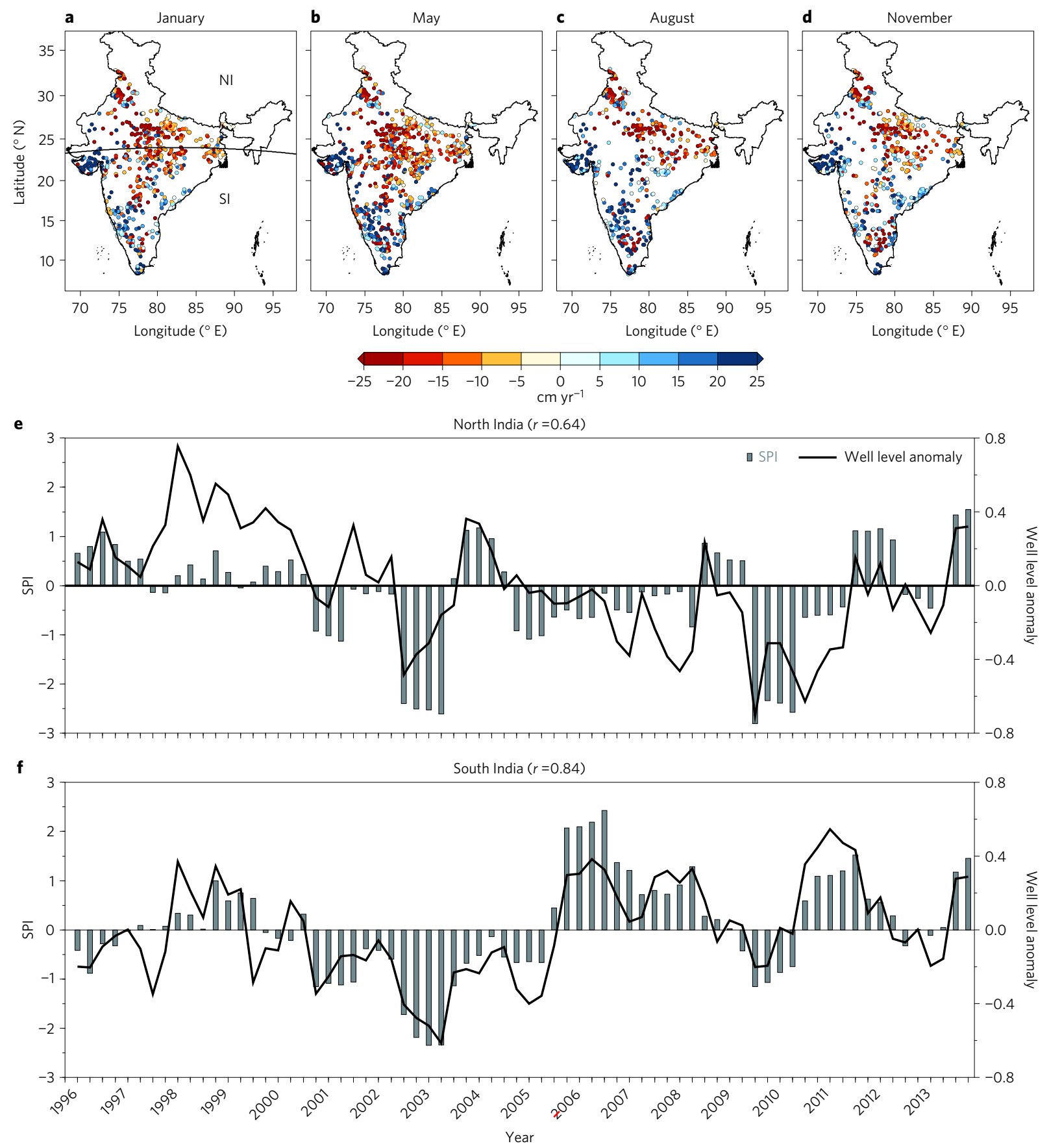

Figure 2 | Changes in groundwater level in observation wells during 1996-2013 and their linkage with precipitation. a-d, Observed trend in groundwater table for the months of January, May, August, and November for 1996-2013. Trends were estimated using the non-parametric Mann-Kendall trend test and Sen's slope (wells that show statistical significant changes at the $5 \%$ level are shown). e,f, Relationship between standardized groundwater table anomaly and 12-month standardized precipitation index (SPI) for January, May, August, and November for northern India (above $23^{\circ} \mathrm{N}$ ) and for southern India (below $23^{\circ} \mathrm{N}$ ), respectively.

1996-2013 in a majority of observation wells located in north India $\left(23^{\circ}\right.$ north, Fig. $\left.2 \mathrm{a}-\mathrm{d}\right)$. Moreover, we find that the number of wells with significant $(p$-value $<0.05)$ declines is higher for the non-monsoon season than for the monsoon season, which may be due to increased pumping during the non-monsoon season as it is a major crop-growing period (Supplementary Fig. Z). In India, the monsoon season overlaps with a major crop-growing season (Kharif, June to September), in which groundwater pumping may be high during monsoon deficit years. In the Rabi (October to April) season, however, a majority of crops (for example, wheat) mostly rely on groundwater-based irrigation. Observation wells with significant water-level increases $\left(\sim 5-20 \mathrm{~cm} \mathrm{yr}^{-1}\right)$ are mainly located in south India, which is consistent with GRACE data (Fig. 1). However, a minority of wells in each region show opposite trends of decreasing groundwater levels in southern India and increasing groundwater levels in northern India, highlighting the complexity and heterogeneity of the data and localized influence of groundwater pumping and recharge (Fig. 2).

Standardized groundwater level anomalies averaged over northwest, north-central, and south India for all four months (January, May, August, and November) represent annual variability and show a close relationship (correlation coefficients $0.55,0.54$, 

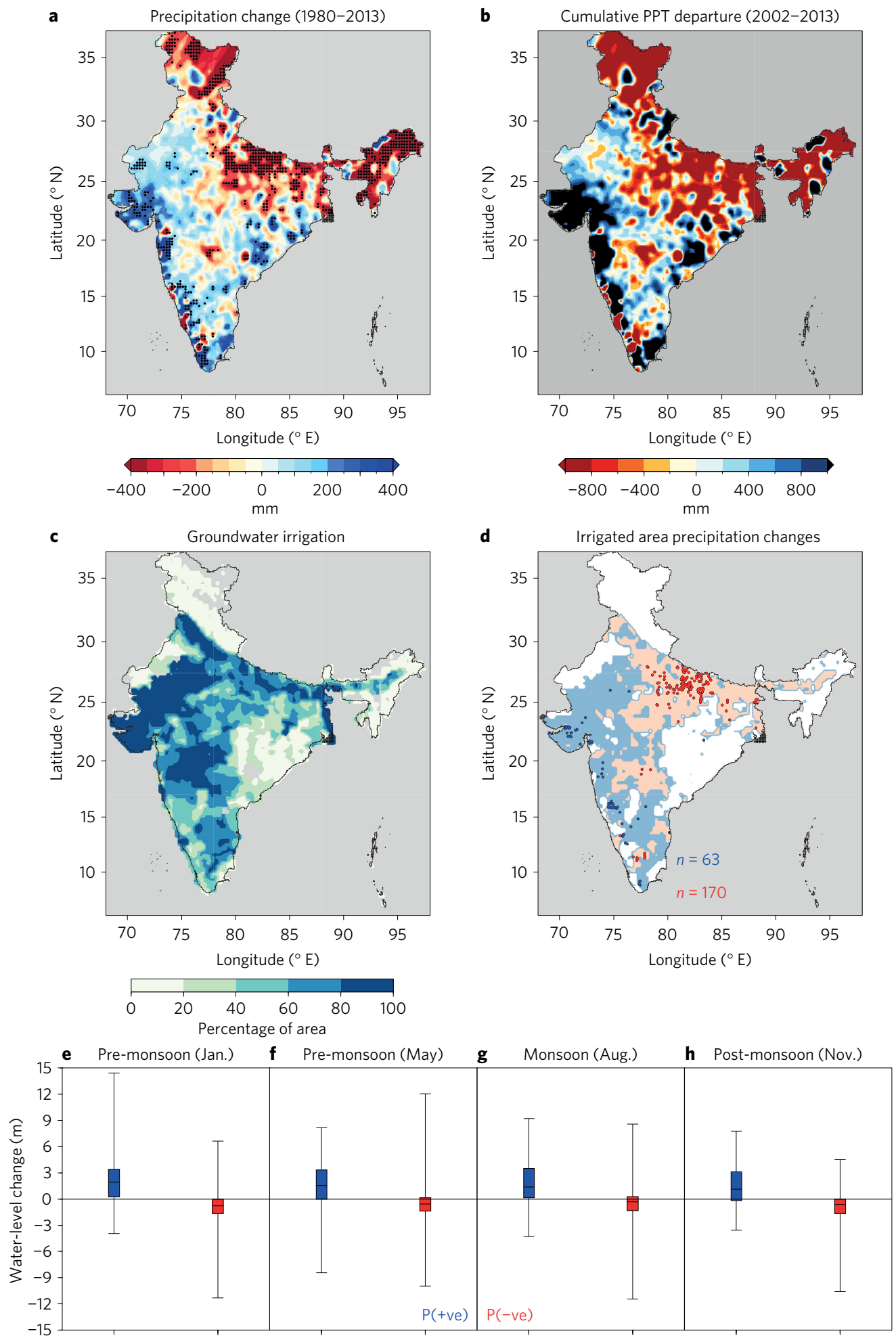

Figure $\mathbf{3}$ | Changes in precipitation in irrigated and non-irrigated areas. a, Changes in the monsoon season precipitation (mm) during $1980-2013$. Changes were estimated using the Mann-Kendall trend test and Sen's slope method. b, Cumulative departure of precipitation from long-term mean (1980-2013) for 2002-2013. c, Area (\%) irrigated with groundwater in India according to data obtained from the Food and Agricultural Organization (FAO). d, Areas irrigated with more than $40 \%$ contribution from groundwater (from c) and significantly increasing (blue) and decreasing (pink) precipitation during 1980-2013; red and blue dots represent locations of observation wells with significant trends in groundwater levels. e-h, Median trend in water-level change $(\mathrm{m})$ in groundwater wells that are located in the region that experienced significant positive (blue bars, 63 wells) or negative changes (red bars, 170 wells) in precipitation and more than $40 \%$ area irrigated (as shown in d).

and 0.80 , respectively) with the 12 -month (Supplementary Table 1) standardized precipitation index (SPI) for 1996-2013. Precipitation deficit in north India influences soil moisture, groundwater abstraction, and evaporative demands, as shown for the drought year of 2009 (Supplementary Section 1 and Supplementary Fig. 3). Evaporative stress index (ESI, ratio of evapotranspiration 
a

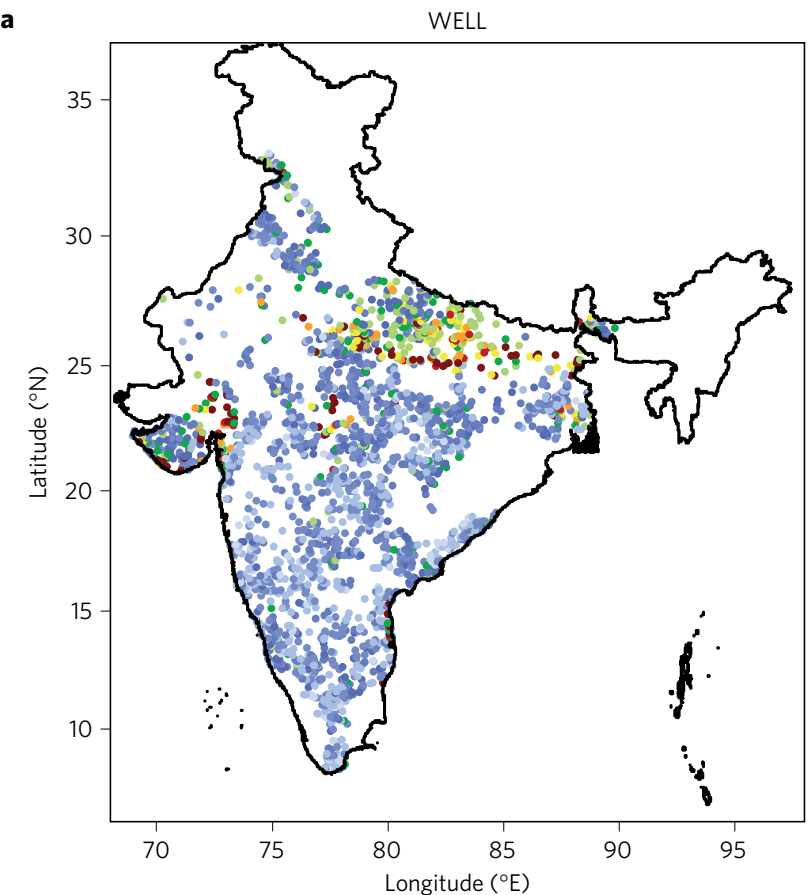

b

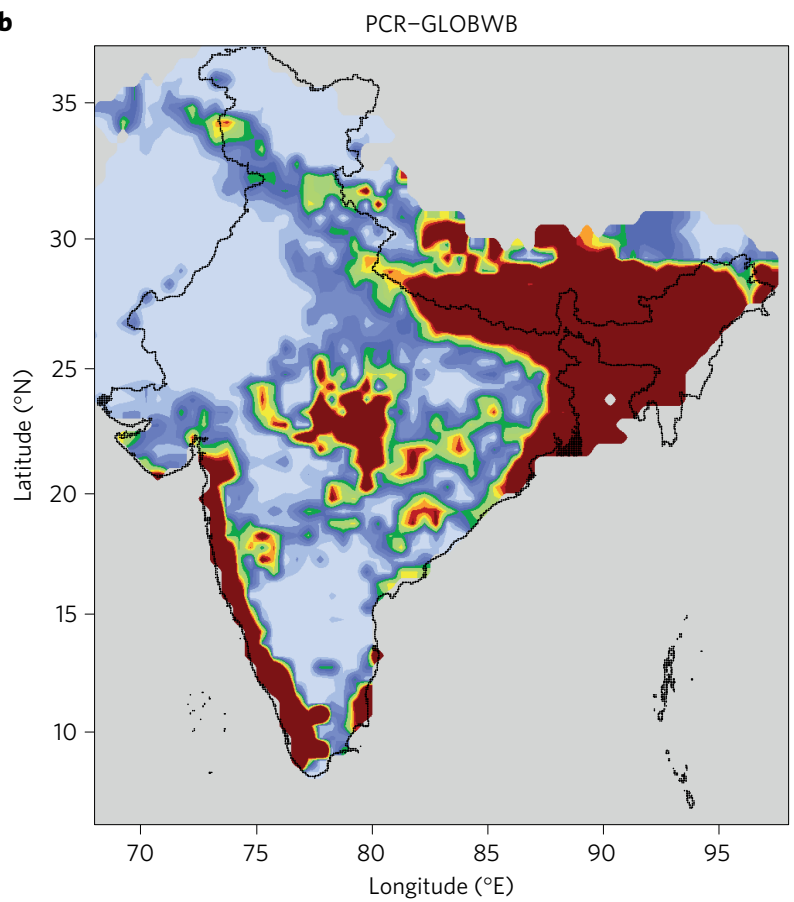

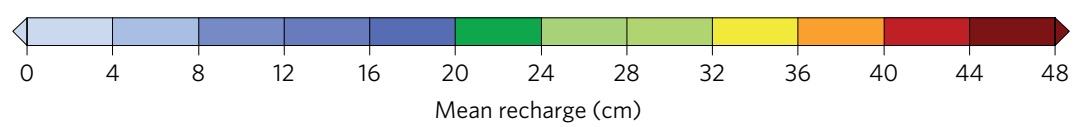

c

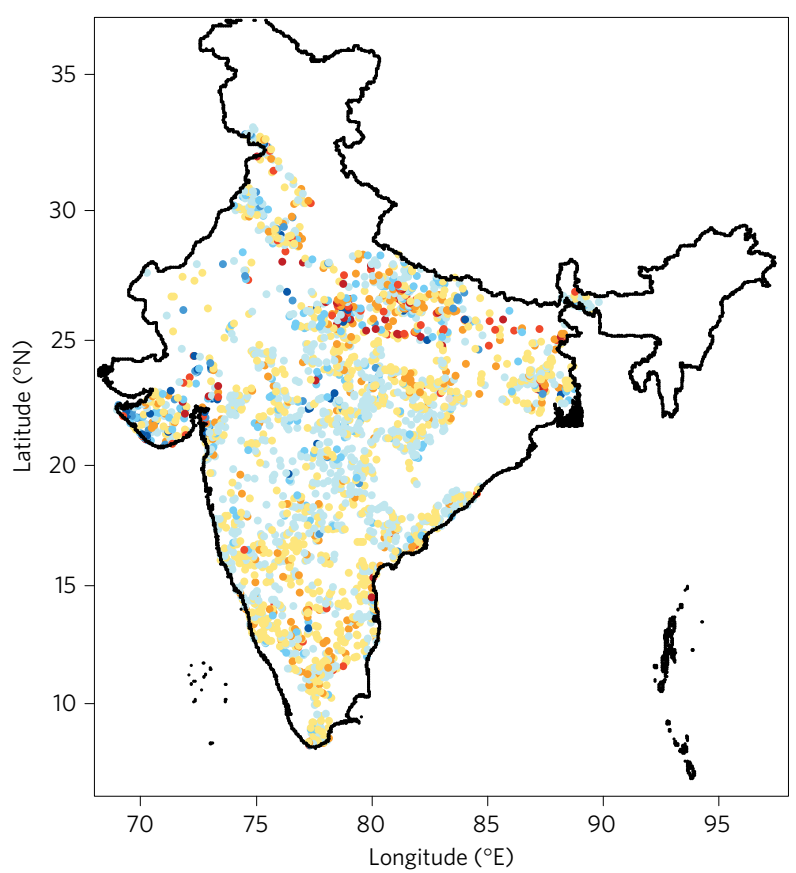

d

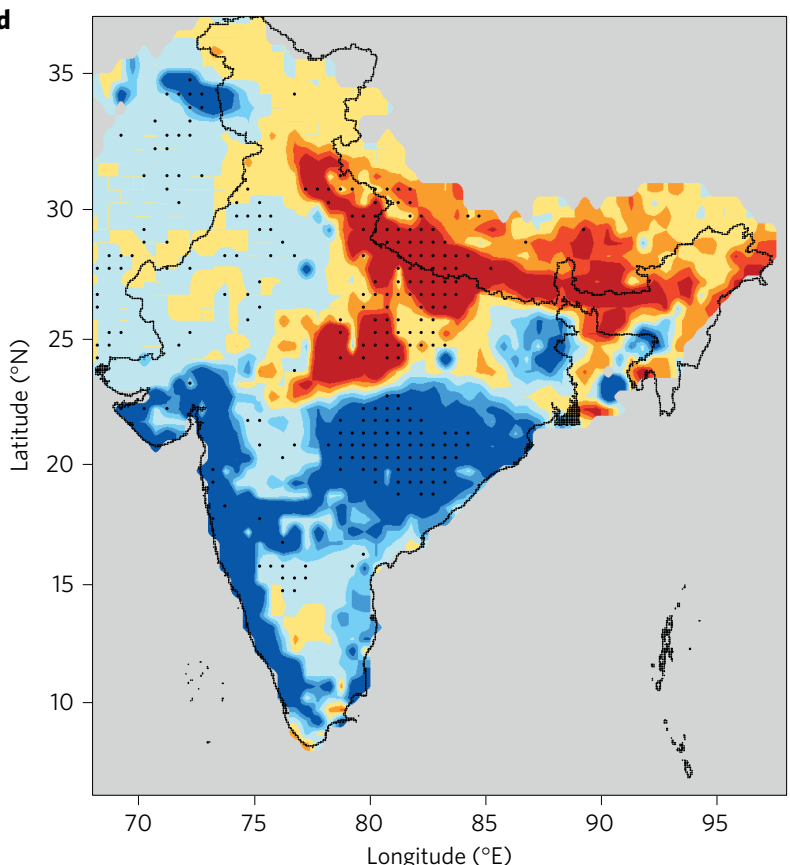

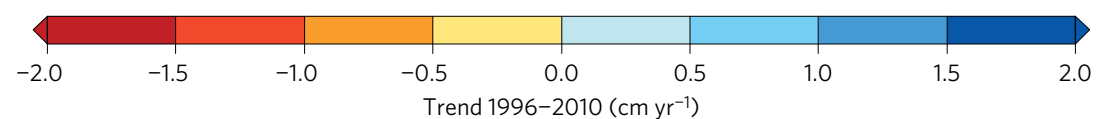

Figure 4 | Groundwater recharge from water-level observations and the PCR-GLOBWB model for 1996-2010. a, Mean annual (climatology) groundwater recharge (cm) estimated using the water-table fluctuation method (see Methods for details) for 1996-2010. b. Same as a, but using recharge data from the PCR-GLOBWB model. c, Change (trend/year multiplied by the total duration (1996-2010)) in groundwater recharge for observation wells estimated using the non-parametric Mann-Kendall test and Sen's slope method for 1996-2010. d, Same as c, but for the recharge estimates from the PCR-GLOBWB model.

$(\mathrm{ET}) /$ potential evapotranspiration (PET)) estimated using Moderate Resolution Imaging Spectroradiometer (MODIS) satellite data for 2002-2013 (Supplementary Fig. 2) shows a significant increase during the post-monsoon season in the majority of northern India, which may be due to increased groundwater abstraction for irrigation as a precipitation contribution to 
a
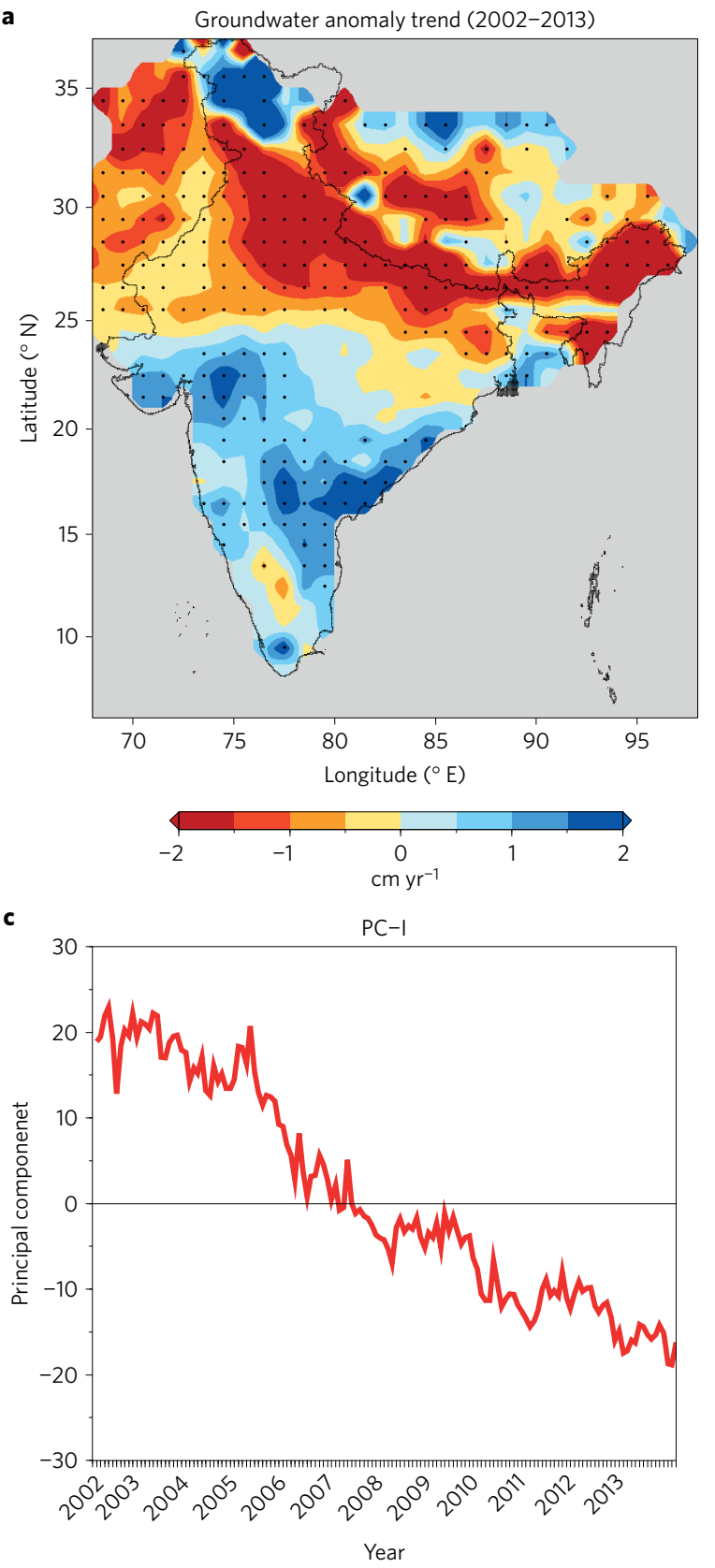

b

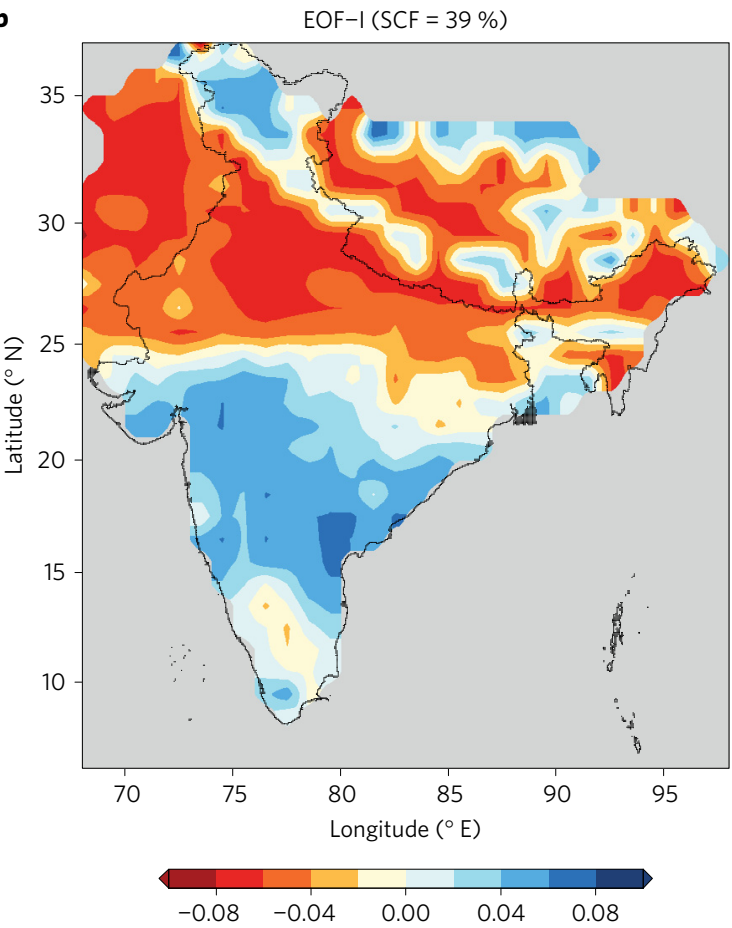

d

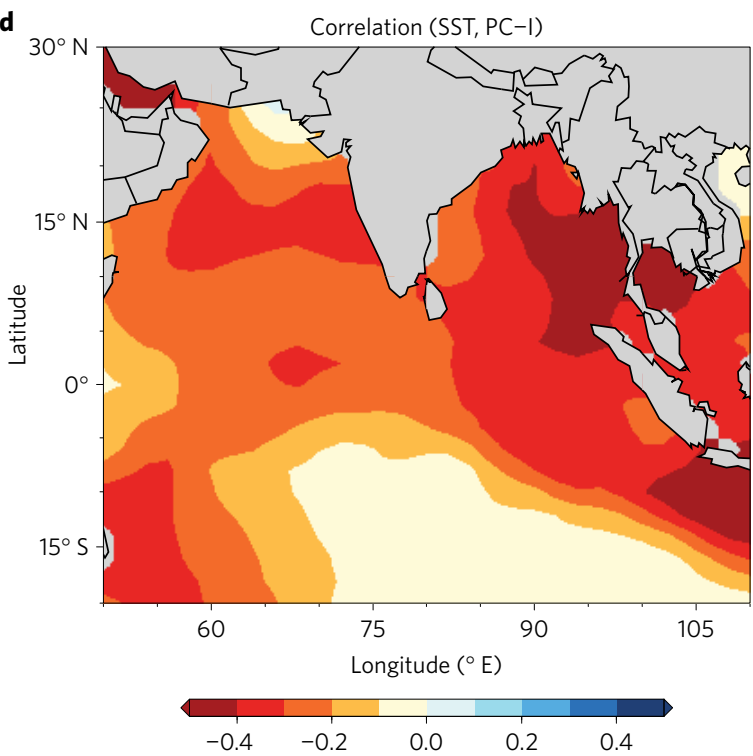

Figure 5 | Linkage between groundwater storage variability and Indian Ocean SST. a, Trend ( $\mathrm{cm} \mathrm{yr}^{-1}$ ) in annual groundwater anomaly from GRACE data for 2002-2013. The trend was estimated using the non-parametric Mann-Kendall test and Sen's slope method. Stippling shows areas that experienced statistically significant increases/declines in annual groundwater anomaly. b, Leading mode (EOF-1) of variability obtained using the Empirical Orthogonal Function (EOF) analysis of the annual groundwater anomaly data from GRACE. c, Principal component (PC, PC-1) corresponding to the EOF-1.

d, Correlation between the Indian Ocean SST and PC-1 for 2002-2013.

increased ET is less in the dry season (Supplementary Fig. 1i). Moreover, positive SST anomalies (El-Niño) in the central Pacific Ocean result in precipitation deficit in the monsoon season in north and south India (Supplementary Table 6) and precipitation deficit in 2002 and 2009 can be partially attributed to El-Niño.

\section{Precipitation and groundwater storage variability}

Groundwater storage could be affected by significant declines in the monsoon season precipitation in India after $1950^{11-13}$ if changes in precipitation lead to changes in recharge or groundwater pumping. Declines in the monsoon season precipitation have been observed since 1950, and have continued during 1980-2013 (Fig. 3a,b).
Moreover, cumulative deficit in the monsoon season precipitation showed substantial reductions in precipitation during 2002-2013 in north India (Fig. 3b). Long-term changes in precipitation may affect groundwater storage in north India due to high groundwater persistence, as groundwater levels respond slowly to recharge (Supplementary Fig. 4). We notice that parts of the Gangetic Plain, semi-arid western India (including Gujarat in west-central India), and peninsular India are heavily irrigated with groundwater (Fig. 3b). To evaluate the role of long-term changes in precipitation on groundwater storage, we separated the wells located in the regions with significant increases/declines in precipitation (1980-2013) and heavily irrigated (more than 
$40 \%$ irrigation from groundwater) with groundwater (Fig. 3c,d). We find that wells that are located in the areas that witnessed significant increases in precipitation showed positive median trends in groundwater level (1996-2013) despite these wells being located in the area that is heavily irrigated with groundwater ( h and Supplementary Fig. 5). On the other hand, wells that are located in the areas with significant declines in precipitation showed declines in groundwater tables, although there is a large variability in trends in both cases (Fig. 3e-h). The analysis was repeated for 2002 2013 with consistent results, suggesting that changes in precipitation substantially influence groundwater storage in India. Positive trends in groundwater storage change in south India are consistent with the long-term increase in precipitation ${ }^{10,12}$.

\section{Changes in groundwater recharge}

We estimated annual groundwater recharge from well data using the water-table fluctuation method ${ }^{17}$ and from the PCR-GLOBWB model. We found a substantial fluctuation in water-table depth in the observation wells during 1996-2010, which may be associated with the seasonal variability in precipitation and abstraction (Supplementary Figs 6 and 7). Consistent with model results, mean annual groundwater recharge estimated using the watertable fluctuation method for 1996-2010 showed high recharge in north-central India and Gujarat (Fig. 4a,b), primarily due to higher specific yields (Supplementary Fig. 8). Groundwater wells in north India are located in alluvial (unconsolidated sediment) plains, whereas wells in south India are primarily in bedrock (primarily consolidated sediment or igneous rock), which can affect the time for groundwater recharge in response to precipitation. Moreover, groundwater pumping can substantially reduce the well levels in the low-recharge areas, while in high-recharge areas, streamaquifer interaction can also raise water levels ${ }^{15,16}$. A significant decline in precipitation in the north-central region (Supplementary Fig. 9) resulted in reduced groundwater recharge, as shown by both observation wells and model data (Fig. 4c,d). However, recharge in north and south India may be variable and not always directly related to precipitation. There might be other factors affecting groundwater recharge in India that are not considered in our analysis. For instance, groundwater systems have been modified by the large-scale canal network ${ }^{18}$ for water diversions; however, the influence of canals and other surface water storage structures are not considered in our groundwater recharge estimates, which can be substantial in the drier parts of aquifers ${ }^{18}$. Water losses from unlined and lined canals can be substantial ${ }^{19}$ in the areas where an extensive canal network is present (for example, the Gangetic Plain) contributing to groundwater recharge and water logging ${ }^{19}$. Since the area irrigated by groundwater wells in north and south India is far larger than that irrigated by canals (Supplementary Fig. 10), recharge from canals may not be sufficient to compensate groundwater declines due to abstraction ${ }^{20}$. Moreover, in north India (especially in the Indo-Gangetic Plain), the contribution of glacier melt to streamflow is within only $5-10 \%$ (refs 21,22); therefore, groundwater recharge due to stream-aquifer interactions may not be sufficient to balance the losses due to groundwater abstraction for irrigation in downstream regions.

\section{Relative importance of precipitation and abstraction}

We analysed 12-month SPI and standardized abstraction index (SAI, estimated using recharge from the PCR-GLOBWB model) to investigate the relative contributions of precipitation and groundwater abstraction on changes in groundwater storage (Supplementary Fig. 11B). We separated observation wells located in northwest, north-central, and south India, which showed field significant declines (northwest and north-central) and increases (south) in groundwater level during 1996-2013 (Supplementary Fig. 11A). Long-term mean groundwater abstraction for 1996-2010 was substantially high $\left(\sim 50 \mathrm{~cm} \mathrm{yr}^{-1}\right)$ in northwestern India, which is consistent with the findings of Rodell and colleagues ${ }^{2}$. We found significant increases $(5-10 \mathrm{~cm})$ in groundwater abstraction in northwest India for 1996-2010, whereas significant declines in the monsoon season precipitation (Supplementary Fig. 9) and groundwater recharge (Fig. 4) can be noticed in the northcentral India (Supplementary Fig. 9), indicating different driving factors such as the monsoon season precipitation, recharge, and groundwater abstraction in the northwest, north-central, and south India (Supplementary Fig. 9 and Fig. 4). Annual SPI and SAI are strongly related in northwest and south India, with correlation coefficients of -0.80 ( $p$-value $<0.05)$ and $-0.72(p$-value $<0.05)$, respectively. However, a relatively weaker (correlation $=-0.46$, $p$-value $<0.05)$ relationship between annual SPI and SAI was found in the north-central region (Supplementary Fig. 12 and Supplementary Table 1). Our results show that a precipitation deficit can lead to higher groundwater abstraction in India, as modelled abstraction is strongly related to precipitation (Supplementary Fig. 11B). Correlation between annual SAI and groundwater level anomalies from observation wells is strong in northwest and south India, with correlation coefficients of $-0.62(p$-value $<0.05)$ and -0.55 ( $p$-value $<0.05$ ), respectively (Supplementary Fig. 12D,F). However, we did not find a strong relationship (correlation $=0.31$ ) between groundwater abstraction and groundwater levels in northcentral India.

Linear regression was performed for 1996-2010 using groundwater levels from observation wells, SPI and SAI to evaluate the relative importance (contribution) of precipitation and abstraction on groundwater variability. We find that SPI (12-month) explains 29, 30, and 64\% of total groundwater storage variability in northwest, north-central, and south India, respectively (Supplementary Table 2). Annual groundwater abstraction (12 month-SAI) explains 38, 10, and 30\% of total groundwater storage variability in northwest, north-central, and south India (Supplementary Table 2). However, looking at individual contributions (in total variability of groundwater storage) of annual (12-month) precipitation and abstraction, we find groundwater abstraction (SAI) explains more variability $(38 \%)$ in northwest India, whereas SPI explains more variability in the north-central (30\%) and south India (64\%) (Supplementary Table 2). To understand if the groundwater abstraction is driven by precipitation in India, we estimated the fraction of total variability in annual abstraction (SAI) explained by annual precipitation (SPI). Our results showed that $65 \%$ variability of groundwater abstraction (SAI) in northwest India is explained by the annual precipitation (SPI), indicating that groundwater abstraction for irrigation is higher during precipitation deficit. It is important to note that about $35 \%$ of the variability of groundwater abstraction in northwestern India is contributed by other factors (such as choice of crops, intensive agriculture, subsidized electricity, and market driven prices). Moreover, the model results for abstraction may have a relatively higher uncertainty in the north-central region than in southern India ${ }^{23}$. We evaluated the relative importance of SPI and SAI using dominance analysis ${ }^{24}$ to predict groundwater level anomalies because SPI and SAI are correlated. Results from linear regression and dominance analysis were consistent, indicating a larger role of SPI in groundwater storage variability in south and north-central India (Supplementary Tables 2 and 3). Similar to groundwater storage; we estimated the relative importance of SPI and SAI in groundwater recharge for all three regions. We found that annual precipitation (12-month SPI) explains 50, 91, and $83 \%$ of the total variability of annual groundwater recharge in northwestern, north-central, and south India (Supplementary Table 4). Our results from the regression and dominance analysis showed that the relative contribution from SPI in annual groundwater recharge is higher than SAI in all three regions (northwest, north-central, 
and south) (Supplementary Table 4 and Supplementary Table 5), which further highlights the importance of the role of precipitation on groundwater recharge and abstraction in India.

Year-to-year variability in the monsoon season precipitation is linked to the large-scale climate ${ }^{10,12}$, suggesting large-scale climate may also influence groundwater variability in India. Annual changes in the groundwater anomaly from GRACE showed significant $\left(\sim 2 \mathrm{~cm} \mathrm{yr}^{-1}, p\right.$-value $\left.<0.05\right)$ declines in north India and increases in south India (Fig. 5). The leading mode obtained from the empirical orthogonal function (EOF-1), which explained about $46 \%$ of total squared covariance, exhibited a similar spatial structure to that obtained from trend analysis (Fig. 5a,b). The principal component (PC-1) of the leading mode obtained from the EOF analysis showed consistent declines during 2002-2013, indicating the leading mode represents the trend in groundwater anomaly. Negative correlation between PC-1 and SST anomalies indicates that warmer SST anomalies in the Indian Ocean result in declines in groundwater levels in northern India (Fig. 4d), which can be explained on the basis of the relationship between rainfall and $\mathrm{SST}^{12,13}$, and rainfall and groundwater levels, as shown above. Moreover, the ENSO affects the Indian monsoon rainfall in India ${ }^{10}$, which can also indirectly lead to enhanced warming over the Indian Ocean $^{10,25}$. Consistent with previous studies ${ }^{10,26,27}$, we found that a positive SST anomaly over the central Pacific Ocean results in a similar impact (decline in precipitation) in north and south India (Supplementary Table 6), indicating that contrasting trends in groundwater storage in north and south India are more strongly linked to the SST variability in the Indian Ocean. The role of ENSO on groundwater storage variability, which affects SST over the Indian Ocean ${ }^{10,25,28}$, can be separated ${ }^{29}$ if long-term GRACE data are available.

\section{Significance of untangling impacts on groundwater storage} Groundwater storage plays a key role in Indian agriculture, on which a large population rely directly or indirectly ${ }^{8}$. Although groundwater-based irrigated area has increased in northwest, northcentral, and south India during 2002-2013 (Supplementary Table 7), contrasting trends in groundwater storage in north and south India highlight the importance of precipitation variability. Our results show that the contributions of anthropogenic pumping and precipitation to groundwater variability vary regionally in India-in north-central and south India precipitation is the major contributing factor, whereas in northwest India groundwater pumping is more important. We show that precipitation variability controls groundwater storage and recharge directly or indirectly in the majority of India, which has implications for water management in current and projected climate conditions ${ }^{30-32}$. Although groundwater-based irrigated area has increased in northwest, north-central, and south India (Supplementary Table 7), contrasting trends in groundwater storage in north and south India highlight the importance of precipitation variability. Importantly, other factors impacting groundwater storage (choice of crops, type of irrigation methods, intensive agriculture, subsidized electricity, and increasing trend in irrigated area) and groundwater recharge (aquifer characteristics ${ }^{16}$, depth of water table, presence of canals and surface storage structures ${ }^{23,33}$, pumping-induced recharge $e^{34}$ and abstraction $^{18}$, and stream-aquifer interaction ${ }^{16}$ of glacier-fed rivers $^{22}$ ) may affect the linkage between groundwater storage and precipitation in India. Moreover, several other factors related to irrigation practices and methods, uncertainties in recharge $e^{23,33-35}$, and management practices related to agriculture can influence variability of groundwater storage in the current and future climate $^{28}$. For instance, improving irrigation methods (for example, sprinkler, drip) possibly reduces the return flow from irrigation to groundwater and baseflow, which may be another important factor for irrigation development and groundwater storage change in India. Understanding the relative contribution from precipitation and anthropogenic pumping provides insight into better water management approaches for food and water security in India.

\section{Methods}

Methods, including statements of data availability and any associated accession codes and references, are available in the online version of this paper.

Received 13 June 2016; accepted 2 December 2016; published online XX Month XXXX

\section{References}

1. Tiwari, V. M., Wahr, J. \& Swenson, S. Dwindling groundwater resources in northern India, from satellite gravity observations. Geophys. Res. Lett. 36, L18401 (2009).

2. Rodell, M., Velicogna, I. \& Famiglietti, J. S. Satellite-based estimates of groundwater depletion in India. Nature 460, 999-1002 (2009)

3. Wada, Y., van Beek, L. P. H. \& Bierkens, M. F. P. Nonsustainable groundwater sustaining irrigation: a global assessment. Wat. Resour. Res. 48, W00L06 (2012).

4. Döll, P. \& Siebert, S. Global modeling of irrigation water requirements. Wat. Resour. Res. 38, 8-1-8-10 (2002).

5. Scanlon, B. R. et al. Groundwater depletion and sustainability of irrigation in the US high plains and central valley. Proc. Natl Acad. Sci. USA 109, 9320-9325 (2012).

6. Taylor, R. G. et al. Evidence of the dependence of groundwater resources on extreme rainfall in East Africa. Nat. Clim. Change 3, 374-378 (2013).

7. Gandhi, V. P. et al. Groundwater Irrigation in India: Gains, Costs, and Risks (Indian Institute of Management Ahmedabad, 2009).

8. Shah, T. Climate change and groundwater: India's opportunities for mitigation and adaptation. Environ. Res. Lett. 4, 035005 (2009).

9. Siebert, S. et al. Groundwater use for irrigation-a global inventory. Hydrol. Earth Syst. Sci. 14, 1863-1880 (2010).

10. Mishra, V., Smoliak, B. V., Lettenmaier, D. P. \& Wallace, J. M. A prominent pattern of year-to-year variability in Indian summer monsoon rainfall. Proc. Natl Acad. Sci. USA 109, 7213-7217 (2012).

11. Bollasina, M. A., Ming, Y. \& Ramaswamy, V. Anthropogenic aerosols and the weakening of the South Asian summer monsoon. Science 334, 502-505 (2011).

12. Roxy, M. K. et al. Drying of Indian subcontinent by rapid Indian Ocean warming and a weakening land-sea thermal gradient. Nat. Commun. 6, 7423 (2015).

13. Vimal Mishra, R.S. Soil moisture droughts under the retrospective and projected climate in India. J. Hydromet. 2267 2292(2014).

14. Wada, Y., Wisser, D. \& Bierkens, M. F. P. Global modeling of withdrawal, allocation and consumptive use of surface water and groundwater resources. Earth Syst. Dyn. 5, 15-40 (2014).

15. Whittemore, D. O., Butler, J. J. Jr \& Wilson, B. B. Assessing the major drivers of water-level declines: new insights into the future of heavily stressed aquifers. Hydrol. Sci. J. 61, 134-145 (2016).

16. Yue, S. \& Wang, C. Y. Regional streamflow trend detection with consideration of both temporal and spatial correlation. Int. J. Climatol. 22, 933-946 (2002).

17. Gowment of India (Ministry of Water Resoures): Report of the Grow O P O Aethogy (2009).

18. MacDonald, A. M. et al. Groundwater Resources in the Indo-Gangetic Basin: Resilience to Climate Change and Abstraction OR/15/047 (British Geological Survey, 2015).

19. Basharat, M., Hassan, D., Baikani, A.\& Sultan, S. J. Surface water and

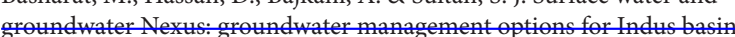
irrigation system. Int. Waterloging Salin. Res. Inst. IWASRI Lahore Pak. Water Power Dew. Auth. Publ. Vol. 155 (2014).

20. MacDonald, A. M. et al. Groundwater quality and depletion in the Indo-Gangetic Basin mapped from in situ observations. Nat. Geosci. 9, 762-766 (2016).

21. Schaner, N., Voisin, N., Nijssen, B. \& Lettenmaier, D. P. The contribution of glacier melt to streamflow. Environ. Res. Lett. 7, 034029 (2012).

22. Immerzeel, W. W., Van Beek, L. P. \& Bierkens, M. F. Climate change will affect the Asian water towers. Science 328, 1382-1385 (2010).

23. Harvey, F. E. \& Sibray, S. S. Delineating ground water recharge from leaking irrigation canals using water chemistry and isotopes. Ground Water 39, 408-421 (2001)

24. Azen, R. \& Budescu, D. V. The dominance analysis approach for comparing predictors in multiple regression. Psychol. Methods 8, 129-148 (2003).

25. Roxy, M. K., Ritika, K., Terray, P. \& Masson, S. The curious case of Indian Ocean warming. J. Clim. 27, 8501-8509 (2014). 
26. Kumar, K. K., Rajagopalan, B., Hoerling, M., Bates, G. \& Cane, M. Unraveling the mystery of Indian monsoon failure during El Niño. Science 314, 115-119 (2006).

27. Shah, H. I. \& Mishra, V.Hydrologic changes in Indian sub-entinental river b $(19012012)$. I. $26672687(2016)$

28. Ashok, K., Guan, Z., Saji, N. H. \& Yamagata, T. Individual and combined influences of ENSO and the Indian Ocean dipole on the Indian summer monsoon. J. Clim. 17, 3141-3155 (2004).

29. Compo, G. P. \& Sardeshmukh, P. D. Removing ENSO-related variations from the climate record. J. Clim. 23, 1957-1978 (2010).

30. Taylor, R. G. et al. Ground water and climate change. Nat. Clim. Change 3, 322-329 (2013)

31. Fishman, R. M., Siegfried, T., Raj, P., Modi, V. \& Lall, U. Over-extraction from shallow bedrock versus deep alluvial aquifers: reliability versus sustainability considerations for India's groundwater irrigation. Wat. Resour. Res. 47, W00L05 (2011).

32. Döll, P. Vulnerability to the impact of climate change on renewable groundwater resources: a global-scale assessment. Environ. Res. Lett. 4, 035006 (2009).

33. Raza, A., Latif, M. \& Shakir, A. S. Long-term effectiveness of lining tertiary canals in the Indus basin of Pakistan. Irrig. Drain. 62, 16-24 (2013).

34. Shamsudduha, M., Taylor, R. G., Ahmed, K. M. \& Zahid, A. The impact of intensive groundwater abstraction on recharge to a shallow regional aquifer system: evidence from Bangladesh. Hydrogeol. J. 19, 901-916 (2011).
35. Wada, Y. et al. Global depletion of groundwater resources. Geophys. Res. Lett. 37, L20402 (2010).

\section{Acknowledgements}

The authors acknowledge funding from the ITRA-Water project. Data availability from the Central Groundwater Board (CGWB), Gravity Recovery and Climate Experiment (GRACE), and India Meteorological Department (IMD) is greatly appreciated.

\section{Author contributions}

V.M. conceived the idea. A.A. collected, analysed the data and developed the methodology. T.G. and Y.W. contributed to discussions of the findings. Y.W. provided groundwater recharge and abstraction data from the PCR-GLOBWB model. V.M. and A.A. wrote the manuscript with contributions from T.G. and Y.W.

\section{Additional information}

Supplementary information is available in the online version of the paper. Reprints and permissions information is available online at www.nature.com/reprints. Correspondence and requests for materials should be addressed to V.M.

\section{Competing financial interests}

The authors declare no competing financial interests. 


\section{Methods}

We used Gravity Recovery Climate Experiment (GRACE) groundwater anomaly, groundwater well observations from the Central Ground Water Board (CGWB), daily precipitation ${ }^{36}$ from India Meteorological Department (IMD), and irrigated area map from the Food and Agriculture Organization (FAO) to understand the driving factors of groundwater variability in India. We derived the groundwater anomaly (GWA) at $1^{\circ}$ spatial resolution after subtracting surface water storage (sum of soil moisture, canopy storage, and surface water) from GRACE terrestrial water storage anomaly (TWSA) for 2002-2013. Monthly TWSA version $05^{37,38}$ was obtained from the Centre for Space Research (CSR) at the University of Texas, Austin. A $300 \mathrm{~km}$ Gaussian filter was applied to reduce the random errors in the data $^{37}$. We applied scaling factors to minimize the attenuation caused due to sampling and post processing. We used monthly surface water storage from the Noah, CLM, VIC, and MOSAIC land surface models, which are available from the Global Land Data Assimilation System (GLDAS) ${ }^{39}$. The ensemble of groundwater anomalies based on GLDAS models (Noah, CLM, VIC, and MOSAIC) was used for the analysis. We used observations from more than 19,000 groundwater wells from CGWB, which are available for the months of January, May, August, and November (frequency of measurements is four times a year) for 1996-2013. However, there are significant data gaps and inconsistencies in the observed records. We selected groundwater observation wells for the analysis that have long-term data and are free from substantial missing data and inconsistencies. We finally selected 2,458 wells with a minimum $15 \mathrm{yr}$ (out of the entire record of $17 \mathrm{yr}$ ) of observations in each month (January, May, August, and Seper. Gridded daily precipitation ${ }^{36}$ at $0.25^{\circ}$ was obtained from IMD for $1980-2014$. For areas outside India, monthly precipitation data were obtained from the Tropical Rainfall Measurement Mission $\left(\right.$ TRMM 3B43 V7) ${ }^{40}$. To understand groundwater variability in irrigated regions, the fraction of total area irrigated with groundwater was obtained from the 'Global Map of Irrigation Areas' (GMIA) version $5^{41}$. The water-table fluctuation method as suggested by the CGWB was used for recharge estimation using the difference between maximum and minimum depths (or fluctuation) of the water table at the observation wells and specific yield (recharge $=$ fluctuation in water table $\times$ specific yield). Specific yield for aquifers in India was obtained by digitizing a map provided by the $\mathrm{CGWB}^{17,42}$.

We used the satellite-derived volumetric soil moisture product from the European Space Agency Climate Change Initiative (ESACCI SMv02.1) ${ }^{43}$ for 1980-2013. Soil moisture trends using the ESACCI data were evaluated with the other products, and consistent results were found ${ }^{43}$. We estimated the evaporative stress index (ESI), which is a ratio of evapotranspiration (ET) and potential evapotranspiration (PET), using data from the Moderate Resolution Imaging Spectroradiometer (MODIS) monthly ET and PET (MOD16) products ${ }^{44}$ at $5 \mathrm{~km}$ spatial resolution for 2002-2013. Higher ESI indicates water-stressed conditions as ET approaches PET

We performed trend analysis based on the non-parametric Mann-Kendall trend test ${ }^{45}$ with Sens's slope estimator ${ }^{46}$. For groundwater level anomalies, trends were estimated for each month for which observations were available to avoid the influence of seasonality. Spatial and temporal correlations in the data set in trend analysis were considered, and a field significance test was performed to evaluate changes at regional scales using the methodology described in Yue and Wang ${ }^{16}$. Please note that trend analysis can be influenced by the start and end year as well as length of the record. Changes for 2002-2013 in the selected variables were estimated by multiplying the trend slope by the number of years. Changes in groundwater anomaly from GRACE, groundwater table from the CGWB, precipitation, soil moisture, maximum temperature, and ESI were estimated for 2002-2013 as well as for the other periods based on the data availability. To represent meteorological drought, the standardized precipitation index (SPI $)^{47}$ was used after fitting the Gamma distribution to monthly precipitation data. Similarly, we estimated the standardized abstraction index (SAI) using the model (PCR-GLOBWB) simulated abstraction data (in linear units) considering cumulative abstraction for a given period. For instance, an $n$-month SPI or SAI represents a standardized anomaly for cumulative precipitation or abstraction for the same period (that is, $n$ months). Daily abstraction data were simulated from the PCR-GLOBWB ${ }^{14}$ model for 1950-2013. The PCR-GLOBWB model simulates water storage for each grid cell at $0.5^{\circ}$ spatial and daily temporal resolutions using two soil layers and an underlying groundwater layer. The model considers groundwater recharge from precipitation and irrigation water, while abstraction is estimated using requirements for irrigation and other sectors.

To evaluate the influence of climate variability and human intervention on groundwater, we selected the regions with increasing and declining trends in precipitation and significant groundwater-based irrigation. Areas were selected that are irrigated more than $40 \%$ with groundwater and have significant increasing or declining trends in the monsoon season rainfall. Groundwater wells falling in these areas were selected and their median trends were evaluated to understand if the monsoon season precipitation is a major driver of groundwater variability in India. To check consistency between groundwater anomalies from GRACE and observation wells, we used aggregated standardized departure fields (standardized anomaly) for wells located in northern (above $23^{\circ}$ ) and southern India (below $23^{\circ}$ ).
We used GRACE groundwater anomalies to estimate persistence (autocorrelation) for northern and southern India, which may influence estimated recharge rates during precipitation deficit years.

To evaluate the relative contribution of SPI and SAI on groundwater storage variability, linear regression was used. The relative contribution was estimated on the basis of the fraction of total variability $\left(R^{2}\right)$ in groundwater storage (represented by well level anomalies) explained by SPI or SAI. The relative contribution of SPI or SAI on groundwater storage variability was estimated by using just one of these (SPI or SAI) as a predictor of groundwater storage anomaly. The relative contribution of SPI and SAI was estimated for 3-24-month accumulation periods for precipitation and abstraction (using 3-24-month SPI for the same month for which groundwater anomaly was used) on groundwater storage anomaly. Similarly, we estimated the relative contribution of SPI and SAI on model-simulated groundwater recharge for north-central, northwestern, and south India. Since SPI and SAI may be correlated, we used dominance analysis ${ }^{24,48,49}$ to estimate the relative importance of SPI and SAI on groundwater storage or recharge (where both are estimated using linear units rather than volumes). In dominance analysis the overall coefficient of determination $\left(R^{2}\right)$ of a predictor variable is computed after evaluating all the possible $(p-1)$ sub-models. The conditional dominance of a variable for each sub-model ( 0 to $p-1)$ is evaluated and the predictor with highest average conditional dominance is identified as the largest contributor ${ }^{24,48,49}$.

To evaluate the role of large-scale climate variability on groundwater, we used empirical orthogonal function (EOF) analysis ${ }^{10}$ using GRACE groundwater anomaly for 2002-2013. The leading mode obtained from the EOF analysis (EOF-1) and the corresponding principal component (PC-1) were obtained. Correlation between the detrended PC-1 of annual groundwater anomalies from GRACE and SST anomalies over the Indian Ocean was estimated. SST data were obtained from the National Climatic Data Center's Extended Reconstructed SST $(\text { ERSSTv3b })^{50}$. We also estimated the correlation between precipitation in north and south India and the Nino 3.4 ENSO index.

Data availability The data used in the study are publicly available and can be directly obtained from the source websites. For instance, GRACE TWS data were obtained from JPL NASA (ftp://podaac-ftp.jpl.nasa.gov/allData/tellus/L3/ land_mass/RL05). GLDAS surface water storage data are available from GSFC NASA (http://disc.sci.gsfc.nasa.gov/services/grads-gds/gldas). Data of satellite (TRMM) and gridded precipitation were obtained from GSFC NASA (http://disc gsfc.nasa.gov/uui/datasets/TRMM_3B43_7/summary) and India Meteorological Department (IMD, http://www.imd.gov.in/Welcome\%20To\%20IMD/Welcome. php), respectively. Soil moisture data used in this study can be obtained from European Space Agency's Climate Change Initiative (ESACCI, http://www.esasoilmoisture-cci.org). Satellite-based evapotranspiration from MODIS (MOD 16) can be obtained from the University of Montana (http://www.ntsg.umt.edu/project/ mod16). Groundwater well data from CGWB are available through Water Resources Information System of India (India-WARIS, http://www.india-wris.nrsc. gov.in/wris.html). Global Map of Irrigation Area (GMIA v5) can be obtained from Food and Agricultural Organization (FAO, http://www.fao.org/nr/water/aquastat/ irrigationmap), while state-level irrigated area information can be obtained from India Stat (http://www.indiastat.com/default.aspx).

\section{References}

36. Pai, D. S. et al. Development of a new high spatial resolution $\left(0.25^{\circ} \times 0.25^{\circ}\right)$ long period (1901-2010) daily gridded rainfall data set over India and its comparison with existing data sets over the region. MAUSAM 65, 1-18 (2014).

37. Landerer, F. W. \& Swenson, S. C. Accuracy of scaled GRACE terrestrial water storage estimates: ACCURACY OF GRACE-TWS. Wat. Resour. Res. 48, W04531 (2012).

38. Swenson, S. \& Wahr, J. Post-processing removal of correlated errors in GRACE data. Geophys. Res. Lett. 33, L08402 (2006).

39. Rodell, M. et al. The global land data assimilation system. Bull. Am. Meteorol. Soc. 85, 381-394 (2004).

40. Huffman, G. J. et al. The TRMM multisatellite precipitation analysis (TMPA): quasi-global, multiyear, combined-sensor precipitation estimates at fine scales. J. Hydrometeorol. 8, 38-55 (2007).

41. Siebert, S., Döll, P., Feick, S., Hoogeveen, J. \& Frenken, K. Global Map of Irrigation Areas (Version, 2007).

42. Central Groundwater Board, Ministry of Water Resources, Government of India: Aquifer Systems of India (CGWB, 2012).

43. Dorigo, W. et al. Evaluating global trends (1988-2010) in harmonized multi-satellite surface soil moisture. Geophys. Res. Lett. 39, L18405 (2012).

44. Mu, Q., Heinsch, F. A., Zhao, M. \& Running, S. W. Development of a global evapotranspiration algorithm based on MODIS and global meteorology data. Remote Sens. Environ. 111, 519-536 (2007)

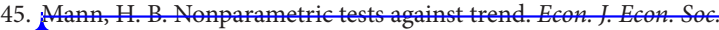
$245-259$ (1945)

46. Sen, P. K. Estimates of the regression coefficient based on Kendall's tau. J. Am. Stat. Assoc. 63, 1379-1389 (1968). 
47. McKee, T. B. et al. The relationship of drought frequency and duration to time scales. Proc. 8th Conf. Appl. Clim. Vol. 17, 179-183 (American Meteorological Society, 1993).

48. Budescu, D. V. Dominance analysis: a new approach to the problem of relative importance of predictors in multiple regression. Psychol. Bull. 114, 542-551 (1993).
49. Nimon, K. F. \& Oswald, F. L. Understanding the results of multiple linear regression beyond standardized regression coefficients. Organ. Res. Methods 16, 650-674 (2013).

50. Smith, T. M., Reynolds, R. W., Peterson, T. C. \& Lawrimore, J. Improvements to NOAA's historical merged land-ocean surface temperature analysis (1880-2006). J. Clim. 21, 2283-2296 (2008). 